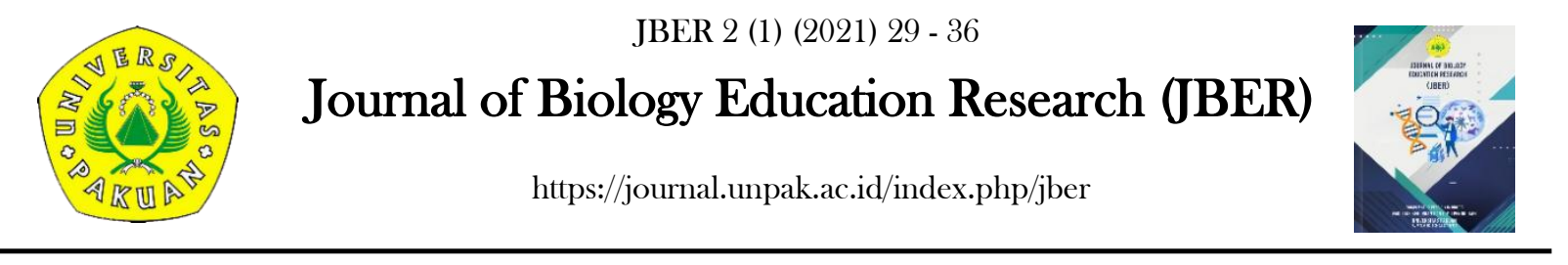

\title{
THE EFFECT OF TRANSFORMATIONAL LEADERSHIP AND COMPENSATION ON PERFORMANCE
}

\author{
Mohammad Mahrum ${ }^{1}$, Ismu Hadjar ${ }^{1}$, Nancy Yusnita ${ }^{1}$ \\ ${ }^{1}$ Universitas Pakuan, Bogor, Indonesia \\ *Email: sadikinse@gmail.com
}

Received: April 2, 2021 Revised: May 18, 2021 Accepted: May 25, 2021

\begin{abstract}
This research is motivated by several interviews with the leader boards of Mafazah Moderen Islamic Boarding School. There are several problems regarding the performance of teachers conveyed by the Head of the Islamic Boarding School. For instance, there are still some teachers who are less disciplined with working hours that have been determined by the staffing department. Some of them often come late and when the school time run out, the teacher always waits for orders and lacks initiative in work. In addition, some teachers give complain about the leadership style of the head in giving attention to teachers personally, the ineffective use of the facilities provided to support work teachers, many complaints about the current compensation system and the reason for compentation are factors that reduced teacher performance. This study was conduated to determine the effect of transformational leadership and compentation on teacher performance at Mafazah Moderen Islamic Boarding School. The number samples use in this study were 140 respondents, using simple linear regression analysis and multiple linear regression. The result show that transformational leadership has an effect on performance, these result are in line with Alzoraki, Rahman and Mutholib (2020), Yeni and Wote (2019, Cahyanu (2018). The result show that compentation has an effect the performance of the results of this study in line with research from Wekesa and Nyaroo MA (2015), Nursakinah (2015), and Ekawati (2018). The result of the analysis show that transformational leadership and compentation have an effect on performance simultaneously. The reslt of this study are in linewith Rismawati and Saly (2018) wich state that transformational leadership and compensation have positive and significabt effect on performance.
\end{abstract}

Keywords: Transformational Leadership, Compentation, Performance

\section{INTRODUCTION}

Susanto (2012: 198) states that teacher performance is influenced by motivational factors, teacher competence and principal leadership. Another opinion from Seharningsih (in Sobirin, 2012: 2) states that there are 4 teacher performance factors, including the ability and high teacher morale, guidance provided by the principal on a regular basis, the ability of the principal by providing supervision so that he can carry out supervision and control of implementation. learning, and the success of the principal in creating a conducive school climate so that teachers are enthusiastic in carrying out learning activities. Tika (2010: 122) someone will always crave respect for the results of their work and expect fair rewards. Based on 
several theories put forward by experts, a thought was found to conduct research on the effect of transformational leadership and compensation on performance, as well as support from the research results of Alzoraki, Rahman and Mutholib (2020), Yeni and Wote (2019), Cahyani (2018) which revealed that transformational leadership affects performance, the results of research from Wekesa and Nyaroo MA (2015), Nursakinah (2019), and Ekawati (2018) show that compensation has an effect on performance and research from Rismawati and Saluy (2018) which shows that transformational leadership and compensation have an effect on performance. Based on the supporting theory and the results of previous research, this research will analyze a) Is there an effect of transformational leadership on performance? b) Is there any effect of compensation on performance? and c) Is there a simultaneous effect of transformational leadership and compensation on performance?

Mathis and Jackson (2009: 378) argue that performance is what employees do or don't do. Employee performance common to most jobs includes the following elements: quantity of results, quality of results, timeliness and results, attendance and co-operation. Teacher performance appraisal is an assessment designed to identify the ability of teachers to carry out their duties through measuring the mastery of competencies shown in their performance (Priansa, 2018: 355). In measuring performance, Robbins (2006: 260) suggests that there are 5 individual performance measurement indicators, namely. a) Quality. Work quality is measured by employees' perceptions of the quality of work produced and the perfection of tasks on employee skills and abilities. b) Quantity, is the amount produced expressed in terms such as the number of units and the number of activity cycles completed. c) Timeliness, is the level of activity that is completed at the beginning of the stated time, seen from the point of view of coordination with the output results and maximizing the time available for other activities. d) Effectiveness, is the level of use of organizational resources (manpower, money, technology, raw materials) maximized with the intention of increasing the results of each unit in the use of resources. e) Independence, is the level of an employee who will later be able to carry out their work functions. The results of research with the same discussion show that performance is simultaneously influenced by transformational leadership and compensation (Rismawati and Saluy, 2018).

The existence of the kyai as the leader of the pesantren is a unique leadership, because the kyai as the leader of an Islamic education institution does not only serve as a boarding school education designer, but covers all pesantren governance (Purwanto and Muhammad, 2015). In terms of the quality of education, pesantren cannot be separated from the leadership role of the kyai, the quality of the kyai's leadership is a measure of the success of the pesantren in maintaining the quality of education (Suhendar, Soejarwo and Basuki, 2017). Assilahi, Sunaryo and Khoirul (2018) that the leadership of the kyai in the pesantren is related to the kyai's way of influencing, inspiring and enabling teachers to work extra with a heart. Bashori (2019) kyai's transformational leadership in a pesantren is described as a leadership style or model that can arouse or motivate members of the organization so that they can achieve optimal performance and exceed the expectations of the organization. Umiarso (2018) kyai's transformational leadership style includes idealized influence behavior, inspirational motivation, intellectual stimulation, individual consideration and individual spiritual greatness. Kurniawati, Bustanur and Mailani (2019), Alzoraki, Rahman and Mutholib (2020), Yeni and Wote (2019), Lestari (2018) and Cahyani (2018) stated that the principal's transformational leadership affects teacher performance.

Compensation is important for teachers, this is because compensation is a source of income for them and their families and has an impact on the psychological condition of teachers in carrying out their duties as educators (Pitri, 2017). Basically compensation can affect teacher performance (Aprijon, 2014). One of the factors that makes teachers active in carrying out their duties professionally is by providing compensation in accordance with their expectations (Widyati, 2019). Compensation has an effect on teacher performance. Based on research from Aisyah, Sarmidin and Andrizal (2020). Hasibuan (2010: 127) argues that the factors that influence the amount of compensation are the supply and demand for labor, the ability and willingness of companies, labor unions or employee organizations, employee work productivity, the government with its laws and presidential decrees, the cost of living or costs. of living, employee positions, employee education and experience, national economic conditions, and the type and nature of work. In measuring compensation, Rivai (2011:357) expresses his opinion on compensation 
indicators that can measure employee expectations, including: a) Direct financial compensation, which consists of salaries, bonuses and incentives. b) Indirect compensation is additional compensation provided based on company policy to all employees in an effort to improve the welfare of employees consisting of facilities such as insurance, benefits, pension, and others. Research results with the same discussion show that partially compensation affects the performance of Wekesa and Nyaroo MA (2015), Ekawati (2018) and Nursakinah (2019).

\section{METHOD}

This type of research used in this research is quantitative research. The quantitative research method is one type of research whose specifications are systematic, well-planned and clearly structured from the start to the making of the research design. In this study, data collection techniques were used by distributing questionnaires. This technique is a technique to obtain respondents' answers to each question arranged according to the variables studied, the results of which are a source of quantitative data for research according to the formulation in the study. In this study, an analysis of the effect of transformational leadership and compensation on performance of teachers at the Mafazah Modern Islamic Boarding School will be analyzed with a frame of mind that describes the relationship between variables as below:

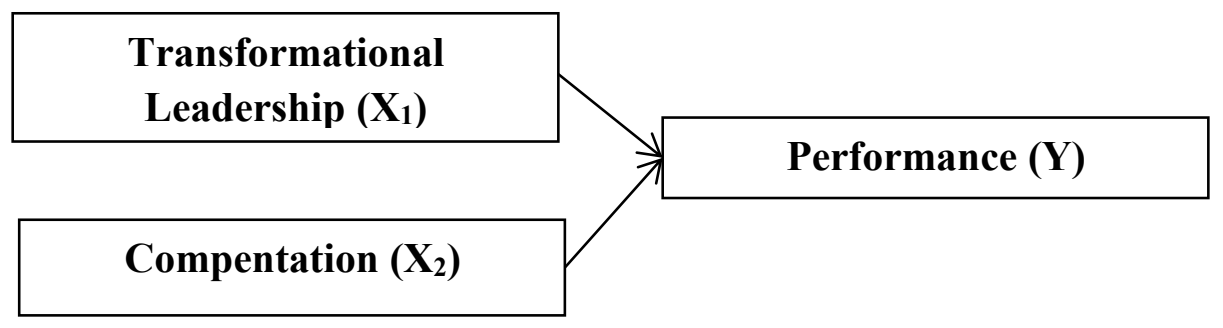

Figure 1. Framework

Based on this framework, the research hypothesis was formed a) Transformational leadership has a positive effect on performance, b) Compensation has a positive effect on performance and c) Transformational leadership and compensation simultaneously have a positive effect on performance.

So that each variable can be operated, an operational definition is formed as follows: a) Performance is an assessment of the work of a teacher by the head of the pesantren. In its measurement using a behavior rating scale with a quality value of 1-5 (Always, often, ever, rarely and never, divided into dimensions and indicators of quality, quantity, timeliness, effectiveness and independence. B) Transformational leadership is the behavior of the leader in changing followers are aware of problems by helping them to view old problems in new ways, and they are able to excite, excite, and inspire followers to put extra effort into followers to achieve organizational goals. The measurement uses a quality value of 1 - 5 (Strongly agree, agree, doubt, disagree and strongly disagree, divided into dimensions of idealized influence, inspirational motivation, intellectual stimulation and individualized consideration. C) Compensation is a teacher's assessment of the reward received as remuneration for his work within a certain period of time, in the measurement using a Likert scale of points $1-5$ (Strongly agree, agree, doubt, disagree and strongly disagree, divided into dimensions of financial compensation and indirect compensation.

\section{RESULT AND DISCUSSION}

1. Characteristics of Respondents 
Table 1. Characteristics of Respondents

\begin{tabular}{llll}
\hline Category & Range (year) & Total & Percentage (\%) \\
\hline Age & $20-30$ & 56 & 40 \\
& $31-40$ & 43 & 30,71 \\
& $41-50$ & 18 & 12,86 \\
Gender & $>50$ & 23 & 16,43 \\
& Male & 77 & 55 \\
Teaching & Female & 63 & 45 \\
Level & SD & 53 & 37,86 \\
& SMP & 48 & 34,89 \\
Educational & SMA & 39 & 27,86 \\
Background & D1 & 0 & 0 \\
& D2 & 0 & 0 \\
& S1 & 0 & 0 \\
& $>$ S1 & 97 & 69,27 \\
& & 43 & 30,71 \\
\hline
\end{tabular}

Respondents based on age category with the highest number were in the age range of 20-30 years with a total of 56 people and a percentage of $40 \%$, while the lowest was in the age range of 41-50 years with 18 people and a percentage of $18 \%$. b) In the gender category, the highest respondents were male with a total of 77 people and a percentage of $55 \%$, and the lowest was female respondents with a total of 63 people and a percentage of $45 \%$. c) In the teaching level category, the highest respondent was at the elementary school teaching level with a total of 63 people and a percentage of $37.86 \%$, and the lowest was at the high school teaching level with a total of 39 people and a percentage of $27.86 \%$. d) In the category of education level, the highest was at the S1 education level with a total of 97 and a percentage of $69.27 \%$, while the lowest was at the SMA, D1, D2 and D3 education levels with a total of $0 \%$.

2. Descriptive Statistical Analysis Table 2. Mean Value of Transformational Leadership Variable Dimensions

\begin{tabular}{llccc}
\hline \multicolumn{1}{c}{ Variabel } & \multicolumn{1}{c}{ Dimension } & Score & Mean & $\%$ \\
\hline Transformational & $\begin{array}{l}\text { Idealized Influence } \\
\text { Leadership }\end{array}$ & 4462 & 3,187 & 33,26 \\
& $\begin{array}{l}\text { Inspirational } \\
\text { Motivation }\end{array}$ & 2674 & 2,729 & 26,74 \\
& $\begin{array}{l}\text { Intellectual } \\
\text { Stimuklation }\end{array}$ & 4450 & 3,179 & 33,17 \\
& $\begin{array}{l}\text { Indivudualized } \\
\text { Consideration }\end{array}$ & 1830 & 3,268 & 13,65 \\
\hline
\end{tabular}

From table 2 it can be explained that the highest average score is in the individual consideration dimension with an average score of 3.268 and a percentage of $13.65 \%$ which is in the good enough category, while the lowest is in the inspirational motivation dimension with an average score of 2.729 and a percentage of $26.74 \%$ was in the good enough category.

Table 3. Average Value of the Compensation Variable Dimensions

\begin{tabular}{cllcc}
\hline Variable & \multicolumn{1}{c}{ Dimension } & \multicolumn{1}{c}{ Score } & Mean & $\%$ \\
\hline Compentation & Financial Compentation & 3077 & 3,140 & 21,99 \\
& Indirect Compentation & 10918 & 3,391 & 78,01 \\
\hline
\end{tabular}

From table 3 it can be explained that the compensation dimension with the highest average value is in indirect compensation with an average score of 3.391 and a percentage of $78.01 \%$ which is in the quite good category, and the lowest average score is in the financial compensation dimension with a score an average of 3,140 and a percentage of $21.99 \%$ are in the quite good category. 
Table 4. Average Value of Performance Variable Dimensions

\begin{tabular}{cllll}
\hline Variable & Dimension & Score & Mean & $\%$ \\
\hline Performance & Quality & 3152 & 3,216 & 21,67 \\
& Quantity & 2442 & 3,489 & 16,79 \\
& Time & 4592 & 3,644 & 31,58 \\
& Effectivity & 1933 & 3,452 & 13,29 \\
& Independence & 2424 & 3,463 & 16,67 \\
\hline
\end{tabular}

From table 4, it can be explained that the dimension with the highest average score is in the time dimension with an average score of 3.644 and a percentage of 31.68 which is in the good category, while the lowest is in the quality dimension with an average value of 3,216 and a percentage of $21,67 \%$ fall into the fairly good category.

3. Hypothesis Testing

Table 5. Hypothesis Test

\begin{tabular}{|c|c|c|c|c|c|c|}
\hline Formulation & & Regression equation & $\begin{array}{c}\text { Correl } \\
\text { ation } \\
\text { Coeffi } \\
\text { cient }\end{array}$ & $\begin{array}{c}\text { Determin } \\
\text { ation of } \\
\text { coefficien } \\
t\end{array}$ & $\begin{array}{l}\text { Signific } \\
\text { ance test }\end{array}$ & Consultion \\
\hline \multirow{5}{*}{$\begin{array}{l}\text { Effect } \\
\text { transformational } \\
\text { leadership } \\
\text { performave } \\
\text { Effect } \\
\text { compoentation } \\
\text { performance }\end{array}$} & of & $\mathrm{Y}=13,330+0,950\left(\mathrm{X}_{1}\right)$ & 0,797 & $63,5 \%$ & $t_{\text {hitung }}$ & \multirow{5}{*}{$\begin{array}{l}\text { H0 Rejected } \\
\text { H1 Accepted } \\
\text { KT impact } \\
\text { to KI } \\
\text { H0 Rejected } \\
\text { H1 Accepted } \\
\text { KO Impact } \\
\text { to KI }\end{array}$} \\
\hline & & & & & $(15,497)$ & \\
\hline & to & & & & $\begin{array}{l}t_{\text {tabel }} \\
1,656>\end{array}$ & \\
\hline & $\begin{array}{l}\text { of } \\
\text { to }\end{array}$ & $\mathrm{Y}=53,867+0,500\left(\mathrm{X}_{2}\right)$ & 0,486 & $23,6 \%$ & $\begin{array}{l}t_{\text {hitung }} \\
(6,532)\end{array}$ & \\
\hline & & & & & $\begin{array}{l}>\quad t_{\text {tabel }} \\
(1656)\end{array}$ & \\
\hline $\begin{array}{l}\text { Effect } \\
\text { transformational }\end{array}$ & of & $\begin{array}{l}Y \\
13,065+0,944\left(X_{1}\right)+0,00\end{array}$ & 0,797 & $63,5 \%$ & $\begin{array}{l}F_{\text {hitung }} \\
(119,22\end{array}$ & $\begin{array}{l}\text { H0 Rejected } \\
\text { H1 Accepted }\end{array}$ \\
\hline $\begin{array}{l}\text { leadership } \\
\text { compentation } \\
\text { performance }\end{array}$ & $\begin{array}{r}\text { and } \\
\text { to }\end{array}$ & $8\left(X_{2}\right)$ & & & $\begin{array}{l}8) \quad> \\
F_{\text {tabel }} \\
(3,91)\end{array}$ & $\begin{array}{l}\mathrm{KT} \text { and } \mathrm{KO} \\
\text { Impact to } \mathrm{KI}\end{array}$ \\
\hline
\end{tabular}

Mafazah Modern Islamic Boarding School with a regression coefficient value of 0.950 and a constant of 13.330 with the equation $\mathrm{Y}=13.330+0.950$ (X1) which means that if the current transformational leadership value is 1 it will produce a performance of 14.28 , based on the partial significance test, it is known that tcount is $15.497>\mathrm{t}$ table 1.656 , it can be concluded that transformational leadership has a positive and significant effect on performance. Based on the analysis of determination, it was found that the coefficient of determination was 0.635 , which means that transformational leadership contributed $63.5 \%$ in shaping performance while the remaining $36.5 \%$ was influenced by other factors not examined. This result is in line with Kurniawati, Bustanur and Mailani (2019), Alzoraki, Rahman and Mutholib (2020), Yeni and Wote (2019), Lestari (2018) and Cahyani (2018) which state that there is a positive and significant influence of transformational leadership on performance.

The results show that compensation affects the performance of teachers at the Mafazah Modern Islamic Boarding School with a regression coefficient value of 0.500 and a constant of 53.867, then the regression equation $\mathrm{Y}=53.867+0.500(\mathrm{X} 2)$ is obtained, which means that if the current compensation value is 1 , then it will affect the performance of 54,367, and the value of tcount $6,532>$ ttable 1,656 means that partially compensation affects performance positively and significantly. The results of the analysis of the coefficient of determination found a value of 0.236 , which means that compensation has a contribution of $23.6 \%$ to the performance of teachers at the Mafazah Modern Islamic Boarding School, 
while the remaining $76.3 \%$ is influenced by other factors not examined. The results of this study are in line with research from Wekesa and Nyaroo MA (2015), Ekawati (2018) and Nursakinah (2019). which states that compensation affects performance positively and significantly

The results of the analysis show that transformational leadership and compensation have an effect on performance simultaneously with the regression coefficient $\mathrm{X} 1=0.944$ and $\mathrm{X} 2=0.008$ and a constant value of 13.065, then the equation $\mathrm{Y}=13.065+0.944(\mathrm{X} 1)+0.008(\mathrm{X} 2)$ is found, which means that if the current value of transformational leadership and compensation is 1 then it will affect performance by 14.017, and simultaneously based on the Fcount test it is known that Fcount 119.228> Ftable 3.91 then simultaneously transformational leadership and compensation have a positive and significant effect on teacher performance in Mafazah Modern Islamic Boarding School. The coefficient of determination is known as 0.635 , which means that transformational leadership and compensation contribute to the performance of teachers at the Mafazah Modern Islamic Boarding School by $63.5 \%$, while the remaining $36.5 \%$ is influenced by other factors not examined. The results of this study are in line with Rismawati and Saluy (2018) which state that transformational leadership and compensation have a positive and significant impact on performance.

\section{CONCLUSION}

Currently the transformational leadership carried out by the leadership of the Mafazah Modern Islamic Boarding School is the lowest in the inspirational motivation dimension with an average value of 2.729 , which means that leadership related to the ability to provide motivation and as goal setting is still not enough motivation for teachers to provide maximum performance, so that It is suggested that the leadership of the Islamic boarding school can be even better at providing motivation for teachers so that the performance of teachers at the Mafazah Modern Islamic Boarding School can continue to increase.

Currently based on respondents' responses to the compensation given by Pondok Modern Mafazah to the lowest teacher, what is the financial compensation dimension with an average score of 3,140 , where this financial compensation is related to salaries, incentives and bonuses, it is advisable to further improve teacher performance to suit hopefully, boarding school leaders can provide appropriate financial compensation related to salaries, bonuses and incentives to teachers so that the performance of teachers at the Mafazah Modern Islamic Boarding School can be even better in producing maximum performance

Based on the responses of respondents, currently the dimension of the lowest performance is in the quality dimension related to ability and innovation with an average value of 3,216 . This shows that there is still a lack of ability and innovation from the teacher as an educator to achieve more at work. It is suggested that the boarding schools provide training opportunities for teachers so that they are able to develop their abilities as educators and also develop their initiatives in innovation to be even better.

\section{REFERENCES}

Alawi, Asep Habib Idrus. 2017. Journal of Islamic Education : Kinerja Guru dan Hubungannya Dengan Kualitas Hasil Belajar Siswa Madrasah Aliyah. https://www.researchgate.net. Diakses 17 Desember 2020

Alzoraiki, Mohammed, Rahman, Otman Bin AB, dan Mutholib, Mahazan Abdul. 2020. International Journal : The Effect of the Dimensions of Transformational Leadership on the Teachers's Performance in The Yemeni Public Schools. https://www.reseachgate.net. Diakses 7 Januari 2020

Aprijon. 2014. Jurnal Pendidikan : Pengaruh Kompensasi Terhadap Kinerja Guru SLTA Di Kecamatan Bangkinang. https://www.media.neliti.com. Diakses 17 Desember 2020

Assilahi, Tauffiki Fahharudin, Sunaryo, Hadi dan Khoirul ABS, Muhammad. 2018. Jurnal Riset Manajemen : Kepemimpinan Kharismatik Kyai dan Motivasi Kerja Pengaruhnya Terhadap Kinerja Guru. https://www.media.neliti.com. Diakses 17 Desember 2020 
Bashori. 2019. Jurnal Manajemen Pendidikan Islam : Kepemimpinan Transformasional Kyai Pada Lembaga Pendidikan Islam. https://www.researchgate.net. DIakses 17 Desember 2020

Cahyani, Rizki Dwi. 2018. Jurnal Publikasi : Pengaruh Kepemimpinan Transformasional terhadap Kinerja Guru dengan Motivasi Sebagai Variabel Intervening. http://repository.umy.ac.id. Diakses 1 Desember 2020

Ekawati, Meirisa. 2018. Jurnal Punlikasi : Pengaruh Pemberian Kompensasi Terhadap Kinerja Guru Honorer di SMP Negeri 2 Sungguminasa Kabupaten Gowa. http://repositori.uin-alauddin.ac.id. Diakses 20 Desember 2020

Gandung, Muhammad. 2018. Jurnal Pendidikan dan Kebudayaan : Pengaruh Kompensasi Terhadap Kinerja Guru Pada Yayasan Pendidikan Waskito. https://www.media.neliti.com. Diakses 30 Desember 2020

Hasibuan, Malayu SP. 2010. Manajemen Sumber Daya Manusia. Jakarta: Penerbit Bumi Aksara

Hidayatullah, Rahmat. 2018. Jurnal Pendidikan : Faktor-faktor yang Mempengaruhi Kinerja Guru IPS SMP dan MTS Di Kecamatan Marioriwawo Kabupaten Soppeng. https://www.researchgate.net. Diakses 20 Desember 2020

Ismail, Taufik. 2017. Jurnal Administrasi Pendidikan : Kepemimpinan, Kompensasi, Motivasi Kerja dan Kinerja Guru SD Negeri. https://www.media.neliti.com. Diakses 2 Desember 2020

Kurniawati, Bustanus dan Mailani, Ikrima. 2019. Jurnal Pendidikan : Pengaruh Kepemimpinan Transformasional Kepala Sekolah Terhadap Kinerja Guru. https://www.media.neliti.com. Diakses 17 Januari 2021

Lestari, Iis Dewi. 2018. Pengaruh Gaya Kepemimpinan Transformasional dan Supervisi Kepala Sekolah Terhadap Kinerja Guru di SDN Gugus 7 Kec. Sukmajaya Depok. https://journal.lppmunindra.ac.id. Diakses 19 Desember 2020

Marsita, Mariam dan Imaniyati, Nani. 2017. Jurnal Pendidikan Manajemen Perkantoran : Kompensasi dan Kepuasan Kerja Untuk Meningkatkan Kinerja Guru. https://www.researchgate.net. Diakses 19 Desember 2020

Munawaroh. 2009. Jurnal Publikasi : Pengaruh Gaya Kepemimpinan Transformasional dan Transaksional terhadap Kinerja Guru. http://fe.um.ac.id. Diakses 17 Desember 2020

Mundiri, Akmal dan Bariroh, Afidatul. 2018. Jurnal Pendidikan Islam : Transformasi Representasi Identitas Kepemimpinan Kyai Dalam Hubungan Atasan dan Bawahan. https://doi.org. Diakses 18 Desember 2020

Nursakinah. 2019. Pengaruh Kompensasi Finansial dan Motivasi Mengajar Terhadap Kinerja Guru Ekonomi SMA Negeri di Kabupaten Gowa. http://eprints.unm.ac.id. Diakses 17 Desember 2020

Pitri, Alisyah. 2018. Jurnal Manajemen, Kepemimpinan, dan Supervisi Pendidikan. https://www.media.neliti.com. Diakses 20 Desember 2020

Priansa, Donni Juni. 2018. Perencanaan \& Pengembangan SDM. Bandung. Alfabeta

Purwanto, Ilyas Arif dan Muhammad, Ahmad. Jurnal Membangun Profesionalisme Kurikulum : Kepemimpinan Kyai Dalam Membentuk Etos Kerja Santri. https://www.media.neliti.com. Diakses 17 Desember 2020

Rismawati, R. and Saluy, A. 2018. Jurnal Publikasi Pengaruh Gaya Kepemimpinan Transformasional, Disiplin Kerja Dan Kompensasi Terhadap Kinerja Guru SMK Global Mulia Bekasi. http://amareview.fekon.unand.ac.id. Diakses 18 Desember 2020

Rivai, Veithzal. 2011. Manajemen Sumber Daya Manusia untuk Perusahaan: dari Teori ke Praktik. Jakarta : RajaGrafindo Persada

Robbins, Stephen. 2006. Perilaku Organisasi. Jakarta : Penerbit Salemba Empat.

Rusmini. 2015. Jurnal Pendidikan Keislaman : Gaya Kepemimpinan Kyai Lukman Al-Karim Dalam Pengembangan Lembaga Pendidikan Islam. https://www.media.neliti.com. Diakses 17 Desember 2020

Sarifudin, Agus. 2019. Jurnal Pendidikan Islam : Peningkatan Kinerja Guru Dalam Implementasi Penilaian Sistem SKS Melalui Supervisi Akademik Pengawasan Sekolah. https://www.media.neliti.com. Diakses 18 Desember 2020 
Sobirin, 2012, Budaya Organisasi (Pengertian, makna dan aplikasinya dalam kehidupan organisasi), Yogyakarta: UPP,STIM YKPN

Suhendra, Soejarwo dan Basuki, Ismet. 2017. Jurnal Penelitian Pendidikan : Analisis Kepemimpinan Kyai, Budaya Pesantren, dan Motivasi Kerja Guru Terhadap Mutu Pendidikan Pesantren di provinsi Banten. https://www.researchgate.com. Diakses 12 Desember 2021

Susanto, Ahmad.2012. Perkembangan Anak Usia Dini. Jakarta:Kencana

Tika, Moh Pabundu. 2010. Budaya Organisasi dan Peningkatan Kinerja Perusahaan, cetakan ke-3. Jakarta : PT. Bumi Aksara

Wekesa, Jane Nelima dan Nyaroo, MA Sillas. 2015. International Journal of Scientific and Research Publication : Effect of Compensation on Performance of Public Secondary School Teachers in Eldoret Municipalit Kenya. https://www.ijsrp.org. Diakses 7 Januari 2020

Wibowo. 2011. Manajemen Kinerja. Jakarta : PT. Raja Grafindo Persada.

Widyati, Kus Daru. 2019. Jurnal Sekertari dan Manajemen : Pengaruh Kompensasi Terhadap Kinerja Guru Sekolah Dasar Negeri Jati Waringin X Bekasi. https://www.researchgate.net. Diakses 10 Desember 2020

Yeni, Alice dan Wote, Verawati. 2019. Jurnal Publikasi : Pengaruh Gaya Kepemimpinan Transformasional dan Kepuasan Kerja terhadap Kinerja Guru Sekolah Dasar. https://www.researchgate.net. Diakses 20 Desember 2020 